\title{
Analisis sistem proteksi di PT. PLN (Persero) sektor pembangkitan kendari unit PLTD Wua Wua
}

\author{
Aghnia Nur An Nisa ${ }^{1}$, Marwan ${ }^{2}$, Ahmad Rosyid Idris ${ }^{3}$ \\ 1. Politeknik Negeri Ujung Pandang, Indonesia | aghnianannisa@gmail.com \\ 2. Politeknik Negeri Ujung Pandang, Indonesia | marwan_energy@yahoo.com \\ 3. Politeknik Negeri Ujung Pandang, Indonesia | ahmadrosyid.idris@gmail.com
}

\begin{abstract}
Abstrak
Masalah penentuan nilai setting proteksi dan koordinasi antar rele proteksi sangat berkaitan dengan keandalan suatu sistem. Jika nilai setting proteksi dan koordinasi antar rele proteksi belum jelas/belum diketahui dengan pasti, suatu sistem belum bias dikatakan sebagai sistem yang andal. Sehubungan dengan keandalan sistem tersebut, penelitian ini bertujuan untuk menetukan nilai setting proteksi dan koordinasi antar rele proteksi sehingga apabila terjadi kondisi gangguan, hanya bagian yang terganggu saja yang dilepas dari sistem oleh rele proteksi dan gangguan yang terjadi tidak terjadi meluas. Dalam penelitian ini, rele yang akan dibahas ada 3 buah. Data yang dipergunakan adalah ketika terjadi kondisi gangguan yang meluas dan menyebabkan sistem mengalami padam sebagian. Data yang digunakan dalam penelitian ini diperoleh dari kantor PLN Sektor Pembangkitan Kendari dan unit terkait. Data-data tersebut diperoleh dari history peralatan, sedangkan analisis data dilakukan dengan perhitungan sesuai dengan standar yang digunakan PLN yang dibantu simulator ETAP 12.6.0. Berdasarkan hasil penelitian diketahui bahwa memang terjadi kesalahan setting proteksi sehingga kondisi gangguan meluas dan menyebabkan padam sebagian pada sistem. Hasil perhitungan nilai setting pada rele Outgoing Trafo adalah $36 \mathrm{~A}$, tms 0,239 SI, Arus momen 1356,97 A, td 0,3 (s) DT pada OCR, 138,54 A, tms 0,09282 SI pada GFR, 290,4 A, tms 0,0902 SI pada OCR, 115,47 A, tms 0,08416 SI pada GFR Outgoing Containerized serta 290,4 A tms 0,0722 SI pada OCR, 92,376 A, tms 0,0742 SI pada OCR Incoming Containerized.
\end{abstract}

\section{Kata Kunci}

Rele proteksi, koordinasi, keandalan, OCR, GFR 


\section{TEKNO Jurnal Teknologi, Elektro, dan Kejuruan}

http://journal2.um.ac.id/index.php/tekno | ISSN 1693-8739 / 2686-4657

\section{Pendahuluan}

PLN merupakan suatu badan usaha milik negara (BUMN) yang mempunyai peranan dalam penyediaan jasa tenaga listrik bagi masyarakat. Masyarakat memerlukan penyaluran tenaga listrik yang kualitas dan kuantitas penyalurannya dijaga dengan baik. Namun, dalam melayani kebutuhan tenaga listrik masyarakat, PT. PLN (Persero) juga harus memperhatikan keandalan sistem supaya kontuinitas penyaluran tenaga listrik terjaga.

Berbagai macam gangguan banyak terjadi di PT. PLN. Beberapa gangguan tersebut diantaranya gangguan pada sistem transmisi (Widyastuti dkk, 2014) dan gangguan akibat petir (Rahayu dan Ansyori, 2014) yang berdampak pada jaringan distribusi (Erhaneli, 2016; Mappa, 2017). Melihat perubahan kondisi Sistem Kendari dengan adanya pertambahan PLTMG sebesar $50 \mathrm{MW}$ dan PLTD Comtainerized $18 \mathrm{MW}$ telah merubah kondisi dan konfigurasi sistem.

Pada PT. PLN (Persero) Unit PLTD Wua-Wua terdapat penambahan PLTD Containerized sebanyak 8 Mesin Cummins Containerized yang masing masing sebesar $1 \mathrm{MW}$. Sehingga terdapat penambahan sebesar $8 \mathrm{MW}$ pada Unit PLTD Wua-Wua.

Dengan adanya pertambahan mesin Containerized, maka koordinasi setting proteksi pada bus 20 kV PLTD Wua-Wua perlu dikaji ulang supaya tidak terjadi kesalahan koordinasi proteksi dengan penambahan 8 mesin Containerized (Karyana, 2013). Sesuai dengan data gangguan bahwa telah terjadi beberapa kali trip. Oleh karena itu, pada laporan akhir ini akan membahas tentang koordinasi proteksi supaya apabila terjadi gangguan, proteksi terdekatlah yang bekerja untuk mengamankan titik gangguan dan tidak menyebar luas ke daerah yang tidak mengalami gangguan. Metode yang digunakan yaitu dengan menganalisa data yang telah didapat dari PT. PLN (Persero) Unit PLTD Wua-Wua dan PT. PLN (Persero) Operasi Sistem Sulawesi Tenggara.

\section{Metode}

Metode penulisan jurnal ini dilakukan dengan beberapa metode yaitu studi literatur, observasi data serta wawancara. Teknik analisa / penyelesaian masalah yang diambil disini menggunakan perhitungan secara manual dengan dibuktikan melalui simulator ETAP 12.6.0.

Langkah yang akan dilakukan dengan menggunakan data data yang diperoleh pada tahap observasi yang akan diolah sebagai bahan analisa penelitian seperti (Tleis, 2008):

- Single Line Diagram.

- Data spesifikasi peralatan

- Data setting Relay Proteksi.

Data tersebut digunakan untuk menganalisa permasalahan permasalahan yang sebenarnya terjadi. Setelah Analisa permasalahan telah didapat maka akan dilakukan tahap penyelesaian masalah yang meliputi seperti :

- Perhitungan arus hubung singkat.

- Perhitungan setting OCR dan GFR. 


\section{TEKNO Jurnal Teknologi, Elektro, dan Kejuruan}

http://journal2.um.ac.id/index.php/tekno | ISSN 1693-8739 / 2686-4657

- Analisa koordinasi proteksi.

- Analisa koordinasi proteksi melalui simulator ETAP 12.6.0

Apabila masih terdapat kesalahan koordinasi, maka harus kembali ke nomor 2 untuk mrnghitung ulang nilai setting yang dibutuhkan. Secara singkat diagram alir proses penyelesaian masalah yang akan dilakukan adalah sebagai berikut :

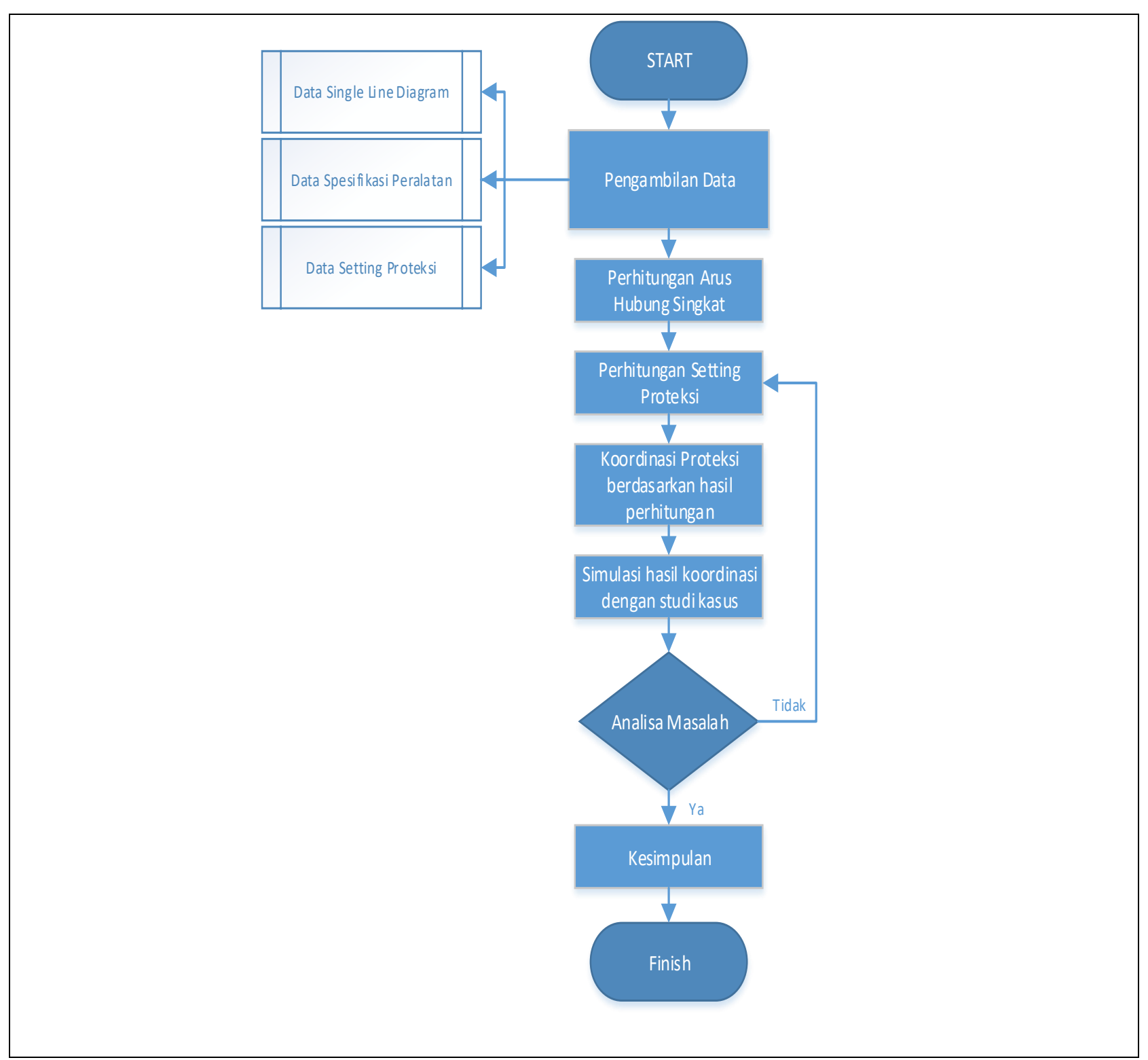

Gambar 1. Flowchart Diagram Proses Penyelesaian Masalah 


\section{TEKNO Jumal Teknologi, Eektro, dan Kejivruan}

http://journal2.um.ac.id/index.php/tekno | ISSN 1693-8739 / 2686-4657

1) Proteksi Sistem Tenaga Listrik

Pengaturan dari satu atau lebih peralatan proteksi, dan peralatan lain yang dimaksudkan untuk melakukan satu atau lebih fungsi proteksi tertentu (Stevenson, 1984). Suatu sistem proteksi yang terdiri dari satu atau lebih peralatan proteksi, transformator pengukuran, pengawatan, rangkaian tripping, catu daya, dan sistem komunikasi bila tersedia. (IEV, 44811-04)

Tujuan utama sistem proteksi adalah mendeteksi kondisi abnormal pada sistem tenaga listrik Memerintahkan trip pada PMT dan memisahkan peralatan yang terganggu dari istem yang sehat, sehingga sistem dapat terus berfungsi (Hermawan, 2014).

Dasar pemilihan proteksi sistem tenaga listrik dan sistem proteksi adalah sebagai berikut: (Karyana, 2013)

- Mengurangi kerusakan pada peralatan yang terganggu dan peralatan yang berdekatan dengan titik gangguan

- Mengurangi gangguan meluas

- Meminimalisasi durasi gangguan

- Meminimalisasi bahaya pada manusia

- Memaksimalkan ketersediaan listrik untuk konsumen

2) Protection Relay

Suatu peralatan yang dirancang untuk menghasilkan perubahan pada rangkaian output apabila nilai parameter input telah mencapai nilai yang ditetapkan sebelumnya. Perlengkapan untuk mendeteksi gangguan atau kondisi ketidaknormalan pada sistem tenaga listrik, dalam rangka untuk membebaskan/ mengisolasi gangguan, menghilangkan kondisi tidak normal, dan untuk menghasilkan sinyal atau indikasi(Saadat, 1999). Rentang waktu sejak gangguan muncul sampai dengan saat kontak keluaran relai terhubung (mengeluarkan perintah trip.

Rentang waktu sejak gangguan muncul sampai gangguan dibebaskan dari sistem (SPLN T5.002-1-2010) Bagian dari jaringan sistem tenaga, dimana telah diaplikasikan proteksi tertentu. (IEV, 448-11-05) Syarat-syarat relay pengaman dikatakan dengan benar adalah (Sarimun, 2012):

a) Cepat bereaksi

Relay harus bekerja bila sistem mengalami gangguan. Kecepatan kerja relay adalah saat relay merasakan adanya gangguan sampai pemutusan $C B$ karena perintah dari relay. Waktu kerja harus secepat mungkin sehingga menghindari kerusakan alat sistem dan mempersempit pemadaman. 


\section{TEKNO Jurnal Teknologi, Elektro, dan Kejuruan}

http://journal2.um.ac.id/index.php/tekno | ISSN 1693-8739 / 2686-4657

b) Sensitif atau Peka

Relay harus dapat bekerja dengan kepekaan yang tinggi, artinya harus cepat sensitive terhadap gangguan di daerahnya meski gangguan tersebut minim, selanjutnya memberikan jawaban.

c) Andal dan Realibility

Keandalan relay dihitung dengan jumlah relay bekerja untuk mgamankan daerah terhadap jumlah gangguan yang terjadi.

d) Murah dan Ekonomis

Relay sebaiknya murah tanpa meninggalkan persyaratan-persyaratan relay.

e) Sederhana

Makin sederhana sistem relay makin baik, mengingat peralatan atau komponen relay memungkinkan kerusakan, jadi semakin sederhana kemungkinan terjadi kerusakan kecil.

- Overcurrent Relay, relay arus lebih adalah suatu alat yang mendeteksi besaran arus yang melalui suatu jaringan dengan bantuan trafo arus. Harga atau besaran yang boleh melewatinya disebut dengan setting.

- Ground Fault Relay, relai gangguan tanah sisi tegangan tinggi transformator generator berfungsi sebagai proteksi cadangan transformator generator terhadap gangguan tanah. Relai ini dipasang pada sisi netral tegangan tinggi transformator generator. Trafo arus dihubungkan paralel sedemikian rupa hingga arus fasa nol dapat dicapai. Aliran fasa nol akan terjadi bila ada kesalahan arus ke tanah dengan tanah netral, jenis proteksi ini tidak akan bekerja bila gangguan tidak melibatkan tanah.

Karakteristik Rele (Grainger, 1994):

a) Rele waktu seketika (Instantaneous time rele)

Rele yang bekerja seketika (tanpa tunda waktu) ketika arus yang mengalir melebihi nilai settingnya, rele ini akan bekerja dalam waktu beberapa mili detik (50-100 ms). Rele ini jarang berdiri sendiri umumnya dikoordinasiakan dengan rele karakteristik yang lain.

b) Rele waktu tertentu (Definite time rele)

Rele ini akan memberikan perintah pada PMT untuk open saat arus yang mengalir melampaui settingnya (Is) dan jangka waktu kerja rele mulai pick up sampai kerja rele diperpanjang dengan waktu tertentu tidak tergantung besarnya arus yang mengerjakan rele.

c) Rele waktu terbalik (Inverse rele)

Rele in iakan bekerja dengan tunda waktu tergantu dari besarnya arus secara terbalik, makin besar arus makin kecil tunda waktunya. Karakteristik ini bermacam-macam dan setiap pabrik dapat membuat karakteristik yang berbeda-beda, karakteristik waktunya berdasarkan IEC 60255 adalah sebagai berikut: 


\section{TEKNO Jurnal Teknologi, Elektro, dan Kejuruan}

http://journal2.um.ac.id/index.php/tekno | ISSN 1693-8739 / 2686-4657

- Standard Inverse

$$
t=\frac{0,14}{\left[\left(\frac{I_{\text {fault }}}{I_{\text {Set }}}\right)^{0,02}-1\right]^{-102}} \times \text { TMS }
$$

- Very Inverse

$$
t=\frac{13_{\imath} 5}{\left[\left(\frac{I_{\text {fault }}}{I_{\text {set }}}\right)-1\right]} \times \text { TMS }
$$

- Extremely Inverse

$$
t=\frac{80}{\left[\left(\frac{f_{\text {fault }}}{I_{\text {set }}}\right)^{2}-1\right]} \times \text { TMS }
$$

Pers. (3)

- Long Time Inverse

$$
t=\frac{120}{\left[\left(\frac{I_{\text {fault }}}{l_{\text {get }}}\right)-1\right]} \times \text { TMS }
$$

Pers. (4)

3) Sistem Per-Unit

$$
\begin{aligned}
& \text { Harga Per Unit }(\text { pu })=\frac{\text { harga sebenarnya }}{\text { harga dasar (base) }} \\
& \begin{array}{l}
I_{b} \quad=\frac{\text { Base daya }\left(\text { MVA } A_{b}\right)}{\sqrt{3 \times \text { Base tegangan }\left(k V_{b}\right)}} \\
Z_{\text {pu }}^{\text {new }} \quad=Z_{\text {pu }}^{\text {old }}\left(\frac{\text { base } k V_{\text {given }}}{\text { base } k V_{\text {new }}}\right)^{2} \cdot \frac{\left(\text { base } M V A_{\text {new }}\right)}{\text { (base } \left.M V A_{\text {given }}\right)}
\end{array}
\end{aligned}
$$

Pers. (6)

Pers. (7) 


\section{TEKNO Jumal Teknologi, Eektro, dan Kejivuon}

http://journal2.um.ac.id/index.php/tekno | ISSN 1693-8739 / 2686-4657

4) Gangguan Hubung Singkat

Gangguan Hubung Singkat 3 Fasa

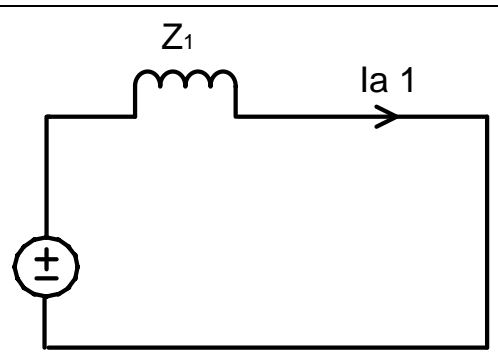

Gambar 2. Rangkaian Pengganti Arus Hubung Singkat 3 Fasa
$I_{\text {fault } 3 \text { fasa }}=\frac{V_{p h}}{Z 1_{\varepsilon q}}$

Kondisi awal:

$I_{a 2}=I_{a 0}=0$

Pers. (9)

$\left|I_{A}\right|=\left|I_{B}\right|=\left|I_{C}\right|$

Pers. (10)

$\left|V_{A}\right|=\left|V_{B}\right|=\left|V_{C}\right|$

Pers. (11)

Arus Fasa:

$$
\begin{aligned}
& {\left[\begin{array}{l}
I_{A} \\
I_{B} \\
I_{C}
\end{array}\right]=\left[\begin{array}{ccc}
1 & 1 & 1 \\
1 & a & a^{2} \\
1 & a^{2} & a
\end{array}\right] \times\left[\begin{array}{l}
I_{a 0} \\
I_{a 1} \\
I_{a 2}
\end{array}\right]} \\
& \mathrm{I}_{\mathrm{A}}=\mathrm{I}_{\mathrm{a} 1} \\
& \mathrm{I}_{\mathrm{B}}=\mathrm{a}^{2} \times \mathrm{I}_{\mathrm{A}}=1 \angle 240^{\circ} \times \mathrm{I}_{\mathrm{A}} \\
& \mathrm{I}_{\mathrm{C}}=\mathrm{a} \times \mathrm{I}_{\mathrm{A}}=1 \angle 120^{\circ} \times \mathrm{I}_{\mathrm{A}}
\end{aligned}
$$

Pers. (15) 


\section{TEKNO Jurnal Teknologi, Elektro, dan Kejuruan}

http://journal2.um.ac.id/index.php/tekno | ISSN 1693-8739 / 2686-4657

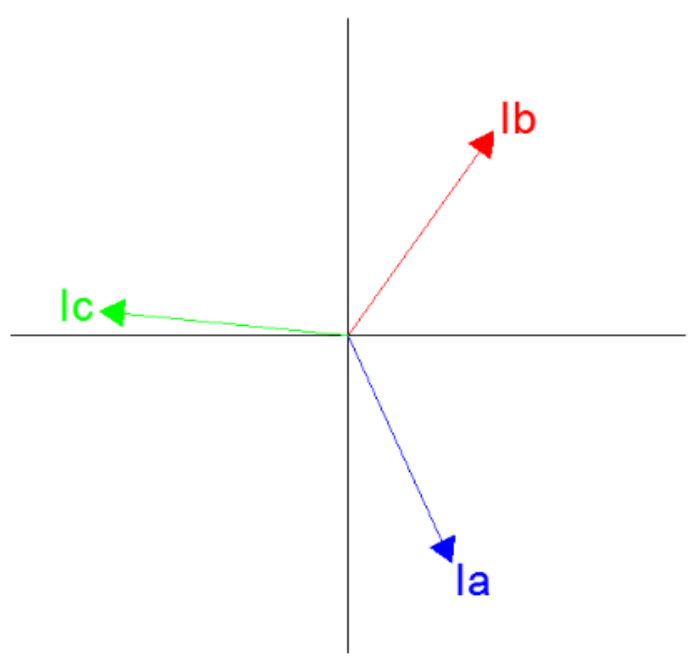

Gambar 3. Vektor Arus Hubung Singkat 3 Fasa

Gangguan Hubung Singkat 1 Fasa ke Tanah.

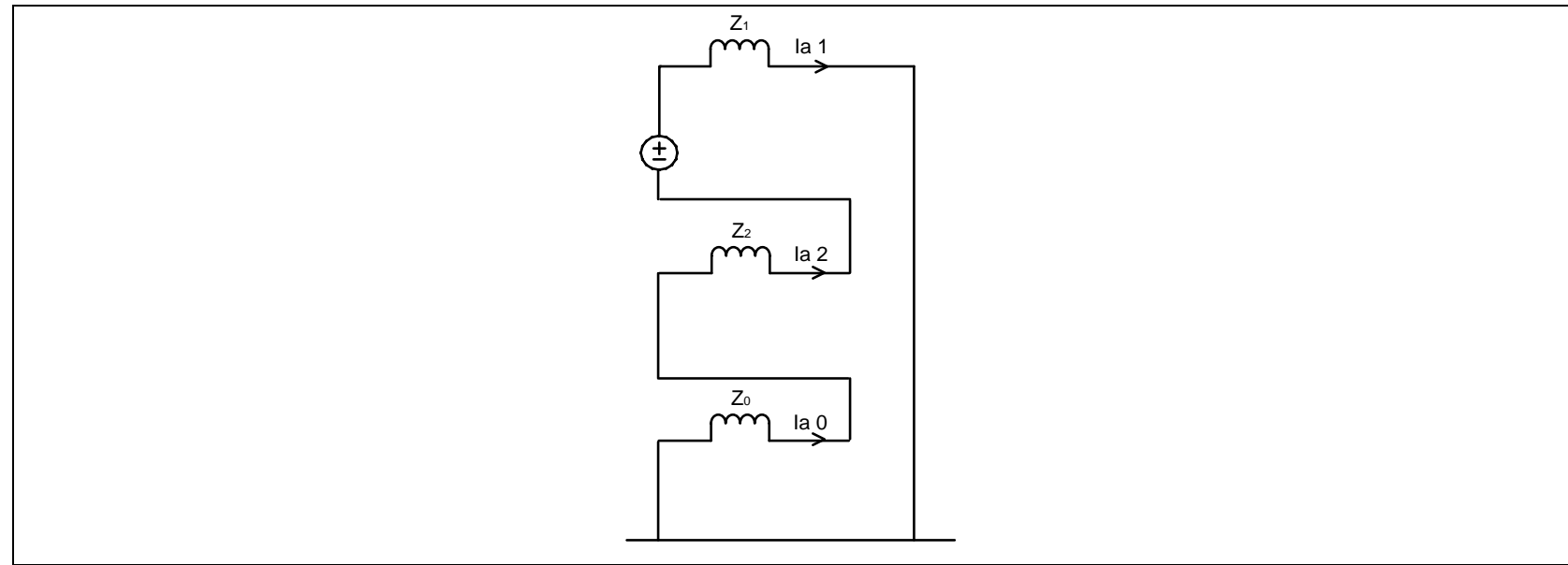

Gambar 4. Rangkaian Pengganti Arus Hubung Singkat 1 Fasa ke Tanah

$$
I_{\text {fault } 1 \text { fasa-ground }}=\frac{V_{p h}}{z_{1 e q}+Z_{2 e q}+z_{0 e q}}
$$

Kondisi awal:

$$
I_{A}=\operatorname{adadan} I_{B}=I_{C}=0
$$

Pers. (17) 


\section{TEKNO Jurnal Teknologi, Elektro, dan Kejuruan}

http://journal2.um.ac.id/index.php/tekno | ISSN 1693-8739 / 2686-4657

$$
I_{a 1}=I_{a 2}=I_{a 0}
$$

Arus Fasa:

$$
\begin{aligned}
& {\left[\begin{array}{l}
I_{A} \\
I_{B} \\
I_{C}
\end{array}\right]=\left[\begin{array}{c}
3 \\
I_{a 1} \\
0 \\
0
\end{array}\right]} \\
& I_{A}=I_{a 1}+I_{a 2}+I_{a 0} \\
& I_{A}=3 \times I_{a 1} \\
& I_{B}=0 \\
& I_{C}=0
\end{aligned}
$$

Pers. $(19$

Pers. (21)

Pers. (22)

Pers. (23)

\section{Hasil}

Sebelum melakukan analisa permasalahan diperlukan data data dan laporan hasil permasalahan yang sering terjadi, data yang di perlukan antara lain adalah:

1. Single Line Diagram

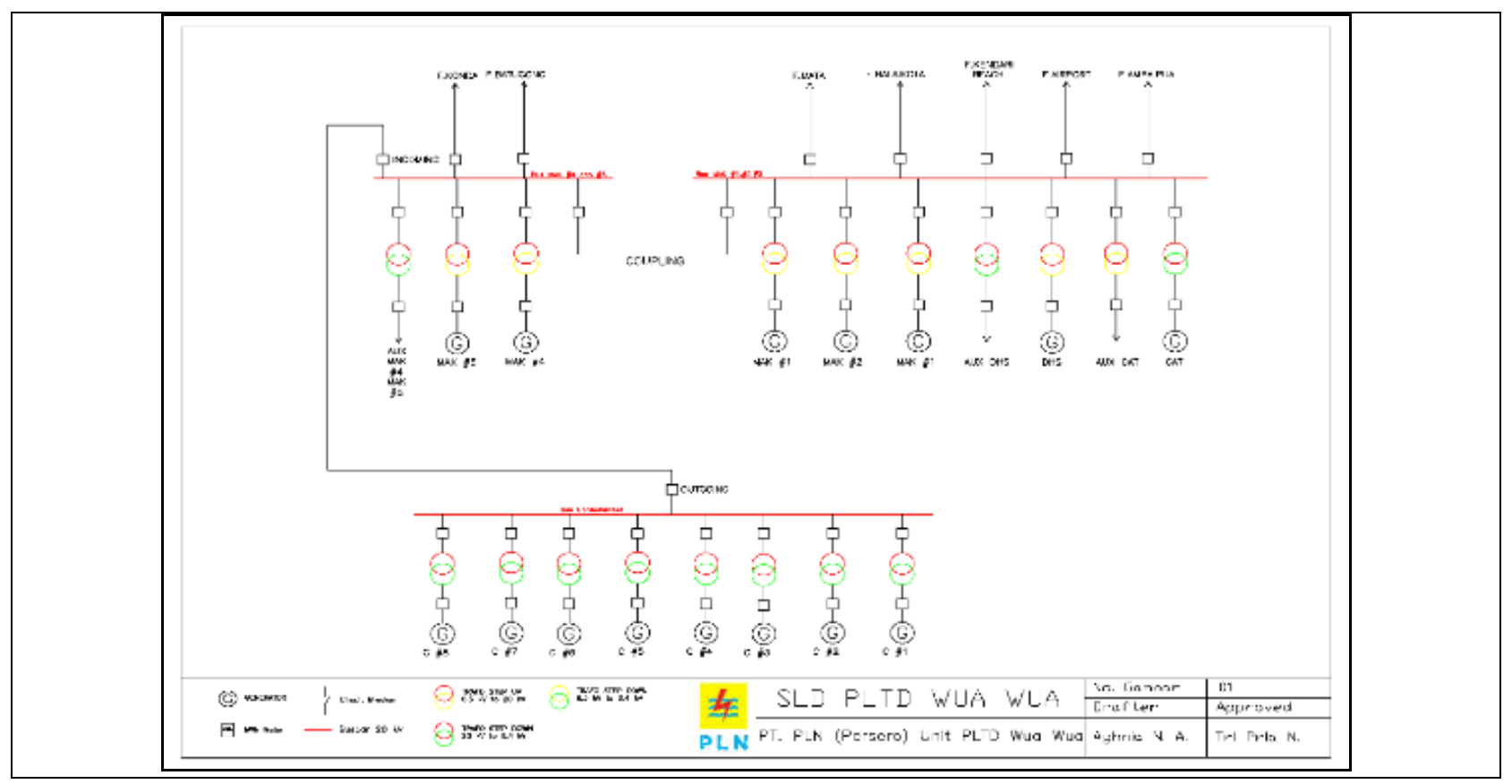

Gambar 5. Single Line Diagram PLTD Wua-Wua

TEKNO Vol. 29 Issue 2, p177-189 | Jurusan Teknik Elektro, Universitas Negeri Malang, Indonesia | September 2019 A.N. A. Nisa, Marwan, A. R. Idris | Sistem Stabilisator Kamera Menggunakan Sensor ... 


\section{TEKNO Jumal Teknologi, Eektro, dan Kejurvon}

http://journal2.um.ac.id/index.php/tekno | ISSN 1693-8739 / 2686-4657

2. Data Setting Proteksi

a) OCR

Merk Relay: SEPAM S40

Tabel 1. Kondisi relay pada arus $(\mathrm{l}>)$

\begin{tabular}{llll}
\hline \multicolumn{1}{c}{ Nama Relay } & \multicolumn{1}{c}{$\mathbf{l}(\mathbf{A})$} & $\mathbf{t d}(\mathbf{s})$ & Curve \\
\hline Outgoing Trafo & - & - & - \\
Outgoing Containerized & 400 & 0,15 & $\mathrm{SI}$ \\
Incoming Containerized & 400 & 0,15 & $\mathrm{SI}$ \\
\hline
\end{tabular}

Tabel 2. Kondisi relay pada arus $(\mid>>)$

\begin{tabular}{llll}
\hline \multicolumn{1}{c}{ Nama Relay } & \multicolumn{1}{c}{$\mathbf{I}>\mathbf{( A )}$} & $\mathbf{t d}(\mathbf{s})$ & Curve \\
\hline Outgoing Trafo & - & - & - \\
Outgoing Containerized & 600 & 0,2 & DT \\
Incoming Containerized & 2600 & 0,1 & DT \\
\hline
\end{tabular}

b) GFR

Merk Relay: SEPAM S40

Tabel 3. Kondisi relay pada arus $\left(\mathrm{I}_{0}>\right)$

\begin{tabular}{llll}
\hline \multicolumn{1}{c}{ Nama Relay } & \multicolumn{1}{c}{$\mathbf{I}_{\mathbf{0}} \mathbf{( A )}$} & $\mathbf{t d}(\mathbf{s})$ & Curve \\
\hline Outgoing Trafo & - & - & - \\
Outgoing Containerized & 60 & 1 & $\mathrm{SI}$ \\
Incoming Containerized & 40 & 0,15 & $\mathrm{SI}$ \\
\hline
\end{tabular}

Tabel 4. Kondisi relay pada arus ( $\left.\mathrm{l}_{0}>>\right)$

\begin{tabular}{llll}
\hline \multicolumn{1}{c}{ Nama Relay } & \multicolumn{1}{c}{$\mathbf{I}_{\mathbf{c}}>\mathbf{>}(\mathbf{A})$} & $\mathbf{t d}(\mathbf{s})$ & Curve \\
\hline Outgoing Trafo & - & - & - \\
Outgoing Containerized & 120 & 0,1 & DT \\
Incoming Containerized & 200 & 0,3 & DT \\
\hline
\end{tabular}

\section{Data Gangguan}

Tabel 5. Data gangguan pada relay

\begin{tabular}{lcl}
\hline \multicolumn{1}{c}{ Tanggal } & Nama Relay & Indikasi \\
\hline 3 Maret 2018 & SEPAM S40 Outgoing Containerized & GFR \\
1 April 2018 & SEPAM S40 Outgoing Containerized & OCR \\
\hline
\end{tabular}




\section{TEKNO Jumal Teknologi, Eektro, dan kejivruan}

http://journal2.um.ac.id/index.php/tekno | ISSN 1693-8739 / 2686-4657

Setelah melalui perhitungan dengan menggunakan rumus nomor 1 hingga 23 dapat disimpulkan bahwa terjadi kesalahan koordinasi proteksi yang mengakibatkan perluasan area yang terdampak gangguan. Sehingga dengan adanya kondisi tersebut, harus dilakukan perhitungan setting baru dan analisa koordinasinya dengan menggunakan simulator ETAP 12.6.0.

\section{Kurva Koordinasi Relay sebelum resetting}

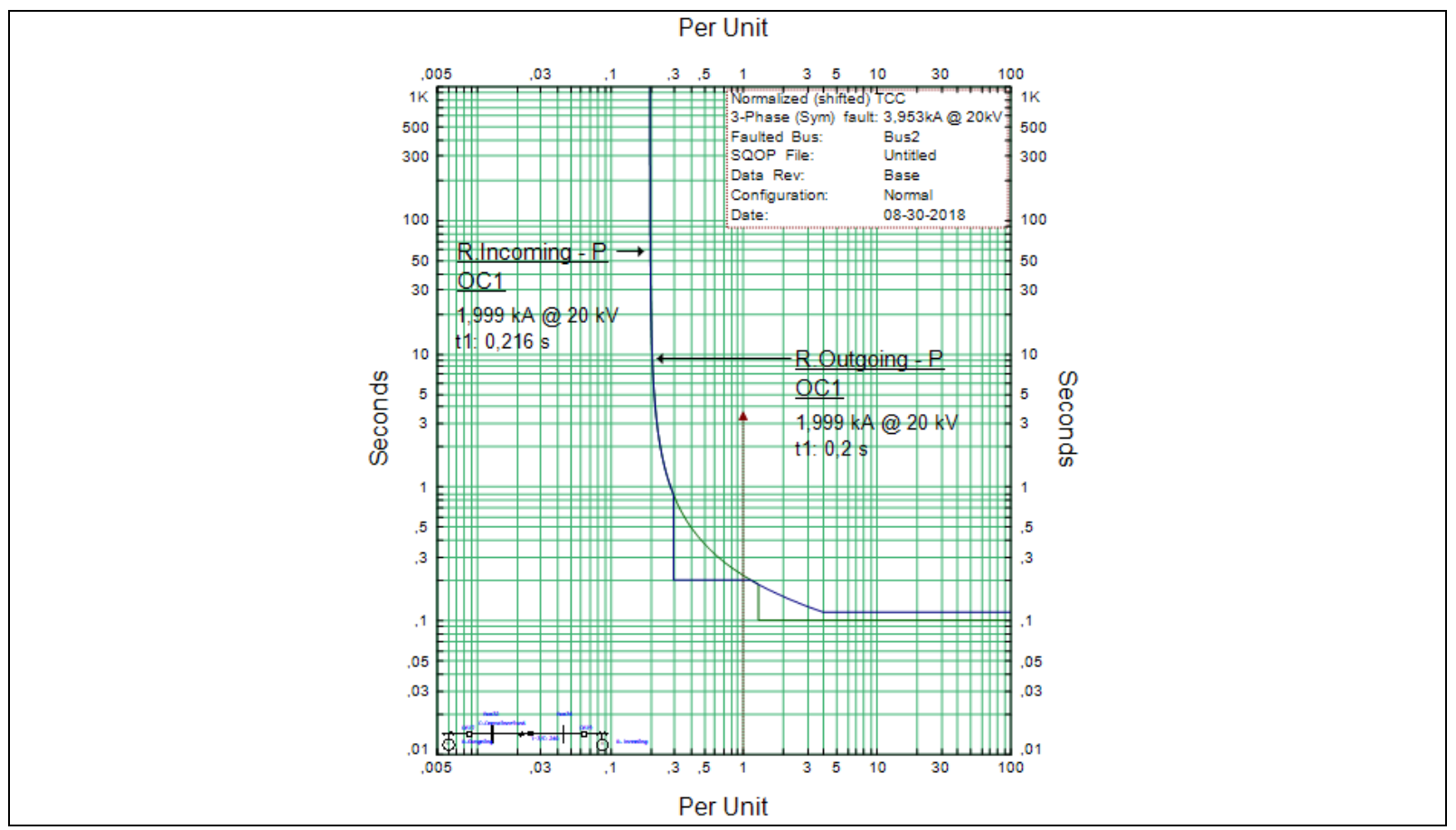

Gambar 6. Kurva Koordinasi Rele Proteksi Saat Terjadi Gangguan

5. Nilai Setting dan Kurva Koordinasi Relay setelah resetting

a) OCR

Merk Relay : SEPAM S40

Tabel 6. Kondisi relay setelah dilakukan resetting pada arus (I>)

\begin{tabular}{llll}
\hline \multicolumn{1}{c}{ Nama Relay } & \multicolumn{1}{c}{ I $\mathbf{( A )}$} & \multicolumn{1}{c}{ td(s) } & Curve \\
\hline Outgoing Trafo & 36,3 & 0,239 & $\mathrm{SI}$ \\
Outgoing Containerized & 290,4 & 0,0902 & $\mathrm{SI}$ \\
Incoming Containerized & 316,8 & 0,0696 & $\mathrm{SI}$ \\
\hline
\end{tabular}




\section{TEKNO Jumal Teknologi, Ekekro, dan Kejurvon}

http://journal2.um.ac.id/index.php/tekno | ISSN 1693-8739 / 2686-4657

Tabel 7. Kondisi relay setelah dilakukan resetting pada arus ( $>>>)$

\begin{tabular}{llll}
\hline \multicolumn{1}{c}{ Nama Relay } & \multicolumn{1}{c}{$\mathbf{l}>\mathbf{>}(\mathbf{A})$} & $\mathbf{t d}(\mathbf{s})$ & Curve \\
\hline Outgoing Trafo & 1356,97 & 0,3 & DT \\
Outgoing Containerized & - & - & - \\
Incoming Containerized & - & - & - \\
\hline
\end{tabular}

b) GFR

Merk Relay : SEPAM S40

Tabel 8. Kondisi relay setelah dilakukan resetting pada arus $\left(\mathrm{I}_{0}>\right)$

\begin{tabular}{llcl}
\hline \multicolumn{1}{c}{ Nama Relay } & I0> (A) & td(s) & Curve \\
\hline Outgoing Trafo & 138,564 & 0,09282 & $\mathrm{SI}$ \\
Outgoing Containerized & 115,47 & 0,08416 & $\mathrm{SI}$ \\
Incoming Containerized & 92,376 & 0,07402 & $\mathrm{SI}$ \\
\hline
\end{tabular}

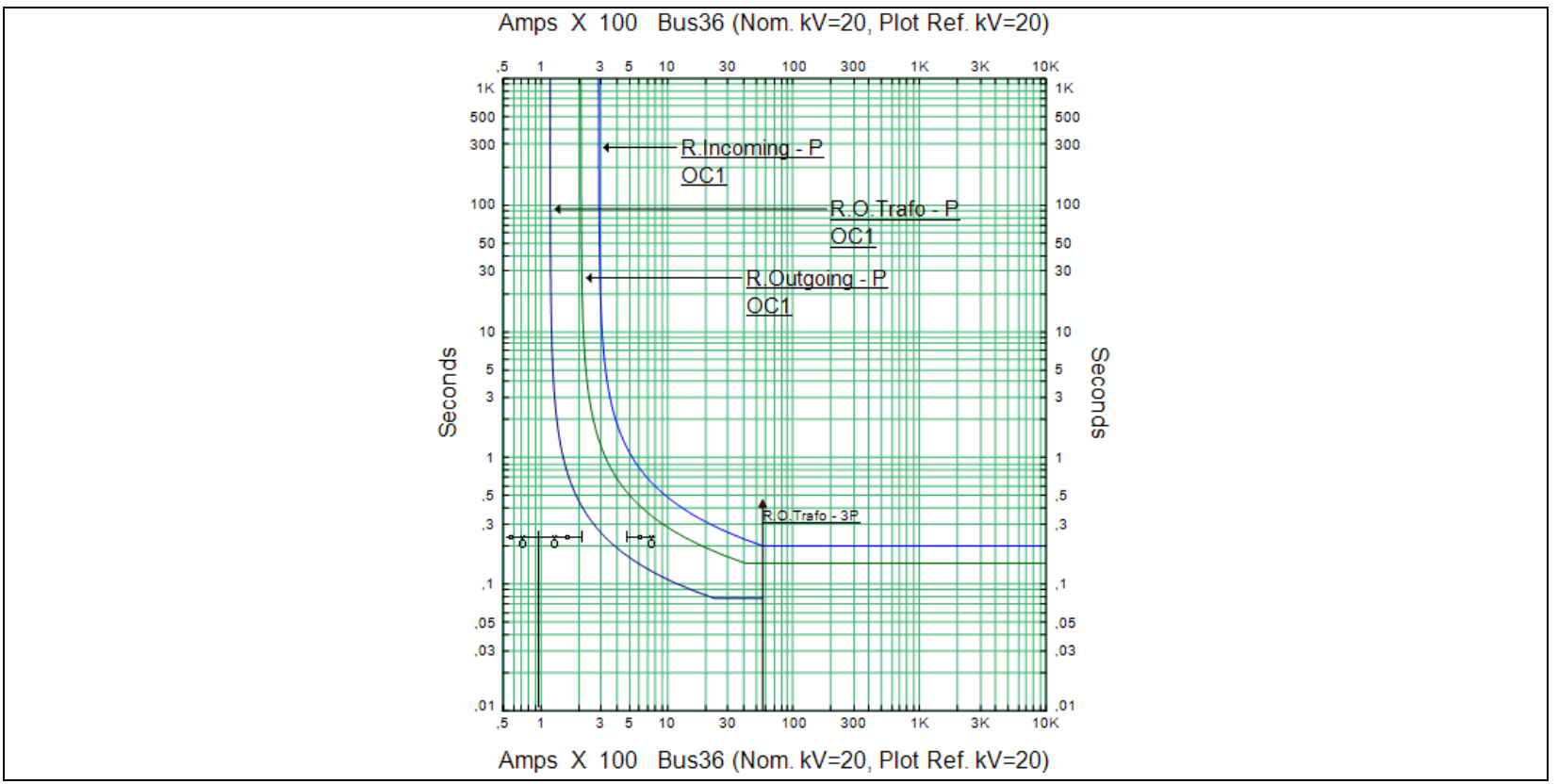

Gambar 7. Kurva Koordinasi Rele Proteksi Saat Terjadi Gangguan Setelah Resetting

Berdasarkan analisa menggunakan perhitungan dan simulasi ETAP 12.6.0 maka dapat diambil kesimpulan antara lain:

- Setelah dilakukan perhitungan secara manual, akan didapatkan nilai setting baru. Setting pada Outgoing Trafo sebelumnya nonaktif setelah dilakukan perhitungan menjadi OCR 36,3 A, tms 0,239 SI dan GFR 138,564 A, tms 0,09282 SI. Setting pada Outgoing Containerized sebelumnya OCR $400 \mathrm{~A}$, td 0,15 s SI dan GFR $60 \mathrm{~A}$, tms $1 \mathrm{~s}$ SI setelah dilakukan perhitungan menjadi OCR 290,4 A, tms 0,0902 SI dan GFR 115,47 A, tms 0,08416 SI 


\section{TEKNO Junnal Teknologi, Eektro, dan Keivuruan}

http://journal2.um.ac.id/index.php/tekno | ISSN 1693-8739 / 2686-4657

Sedangkan pada Incoming Containerized sebelumnya OCR 400 A, td 0,15 s SI dan GFR 40 A, tms $0,15 \mathrm{~s}$ SI setelah dilakukan perhitungan menjadi OCR 316,8, tms 0,0696 SI dan GFR 92,376 A, tms 0,07402 SI.

- Telah terjadi kesalahan koordinasi proteksi pada saat terjadi gangguan yang mengakibatkan sebagian sistem padam karena daerah ganguan yang meluas yang disebabkan rele proteksi pada Outgoing containerized bekerja dan rele proteksi pada outgoing trafo dalam kondisi idle sehingga harus di aktifkan dengan nilai sesuai dengan perhitungan yang telah dibuktikan dengan kurva koordinasi proteksi pada simulator ETAP 12.6.0

\section{Daftar Rujukan}

Erhaneli. 2016. Evaluasi Keandalan Sistem Distribusi Tenaga Listrik berdasarkan Indeks Keandalan Saidi dan Saifi pada PT.PLN (Persero) Rayon Bagan Batu Tahun 2015. Jurnal Teknik Elektro ITP, 5, 2, 120-129.

Grainger, John J. 1994. Power System Analysis. Singapura.

Hermawan, A. 2014. Modul Ajar Transmisi dan Distribusi Tenaga Listrik, Malang: Politeknik Negeri Malang.

Karyana, 2013. Pedoman dan Petunjuk Sistem Proteksi Transmisi dan Gardu Induk Jawa Bali, Jakarta.

Mappa, A. 2017. Analisa Kerja Recloser untuk Memproteksi Jaringan Distribusi di PT. PLN (Persero) Area Sorong. Jurnal Electro Luceat, 3, 1, 1-10.

Rahayu dan Ansyori. 2014. Analisa Proteksi Petir pada Gardu Distribusi 20 KV PT PL (Persero) Rayon Inderalaya. Mikrotiga, 1, 3, 1-8.

Saadat, H, 1999. Power System Analysis, United States of America.

Sarimun, W, 2012. Proteksi Sistem Distribusi Tenaga Listrik, edisi 1, Gamaond, Bekasi.

Stevenson, W. D., 1984. Power System Analysis, Singapura.

Tleis, N. 2008. Power System Modelling and Fault Analysis. Amsterdam, Boston.

Widyastuti, L. N., Suliantoro, H., dan Rumita, R. 2014. Analisis Gangguan Sistem Transmisi Listrik menggunakan Metode Root Cause Analysis (RCA). Industrial Engineering Online Journal, 3, 3, 1-8. 